\title{
Profile of Creative Thinking Skills on Junior High School Students in Science Learning by Gender
}

\author{
Ida Madyani $^{\mathrm{a}^{*}}$, Sri Yamtinah ${ }^{\mathrm{b}}$, Suryadi Budi Utomo ${ }^{\mathrm{b}}$ \\ ${ }^{\mathrm{a}}$ Master of Education in Science Programme, Universitas Sebelas Maret, Indonesia \\ ${ }^{\mathrm{b}}$ Master of Education in Chemistry Programme, Universitas Sebelas Maret, Indonesia \\ *Corresponding author: Ir. Sutami 36 Kentingan street, Jebres, Surakarta, Indonesia. E-mail addresses: idamadyani@gmail.com

\section{a r t i c l e i n f o} \\ Article history: \\ Received: 15 October 2019 \\ Received in revised form: 28 October \\ 2019 \\ Accepted: 08 November 2019 \\ Available online: 31 December 2019 \\ Keywords: \\ Creative thinking skill \\ Science learning \\ Gender \\ 21 st Century

\section{a b s t r a c t}

\begin{abstract}
Creative thinking is one of the essential skills in science learning. Creative thinking skills become a source of strength in the development, invention, and investigation to face the obstacles in the 21st century. This study aimed to determine the creative thinking skills of junior high school students in science learning by gender. This study used descriptive analysis with quantitative data. Data collection by tests, interviews, and observation sheets. The participants of this study were 94 students from three different schools consisting of 35 male and 59 female students. The sampling technique uses purposive sampling. Indicators of critical thinking are fluency, flexibility, originality, and elaboration. Creative thinking skills in this study divided into three categories: high, medium, and low. The result of this study showed that the male students have a high percentage of flexibility, the average percentage in both originality and fluency, and a low percentage in elaboration. Female students have a high percentage in fluency, the medium percentage in elaboration, and a low percentage in both originality and
\end{abstract} \\ flexibility.
}

2019 Scientiae Educatia: Jurnal Pendidikan Sains

\section{Introduction}

Students nowadays have been encouraging to think creatively. The ability to think creatively is one of the abilities students must possess in facing the challenges of the 21 st century. The ability to think creatively belongs to 21 st-century skills or what is known as $4 \mathrm{C}$ (communication, collaboration, critical thinking, and problem-solving, creativity, and innovation). The challenges of the 21 st century are marked by the rapid development of science and technology. The progress of science and technology requires individuals who can adapt to creatively (Munandar, 2009). A nation does not only need abundant resources but also requires the ability to think creatively for the superiority of a country (Mahmudi, 2009).

The ability to think creatively is essential to have because it is a source of human strength in driving progress in terms of tracing, development, and discoveries in the field of science and technology (Ghufron \& Risnawati, 2014). The developing ability to think creatively will create ideas, find interrelated relationships, imagined, and have many perspectives on things. The low capacity of creative thinking will make it difficult for students when problems-solving or questions given by the teacher. Creative thinking students who are flat and not optimal 
suspected because the teacher is not trying to dig students' knowledge and understanding of things creatively (Azhari \& Somakin, 2014). Students tend to be less in trying to find alternative answers and challenging to work on problems that have been developed by the teacher.

One of the subjects that require students to think creatively is science. Also, science is one of the essential foundations in nation-building. Science is developed on three basic dimensions, namely scientific processes, attitudes, and products (Carin \& Sund, 2017). Science learning has the role of preparing students to have the ability to think critically, creatively, logically and take the initiative in responding to issues in society caused by the influence of the development of science and technology (Prayekti, 2006; Bahriah, 2012; Kurnia \& Fathurohman, 2014; Rashid \& Asghar, 2016).

Science in junior high school uses integrated science learning (integrative science), not as a scientific discipline. Integrated science learning is expected to foster scientific process skills are thinking skills that are creative thinking and critical thinking and foster a scientific attitude. Science learning requires individuals who can think creatively. Creative thinking is a thought that seeks to create something new. In general, creative thinking is a mental activity in the form of thinking that can produce concepts, ideas, knowledge, understanding, and discoveries (Gie, 2003). Creative thinking is a form of expressing oneself in a unique way (Abraham, 2016). Limitation of creative thinking due to the indicators and implementation is the creation of something new from various ideas, information, ideas, concepts, experiences, or knowledge contained in the human mind.

The ability to think creatively can be divided into three, namely: (1) fluency, (2) originality, (3) elaboration (Torrance, 1965). Characteristics of creative thinking ability include fluency, flexibility, and novelty (Silver, 1997), while the characteristics of creative thinking skills related to cognition include: thinking fluently, thinking flexibly, thinking original, thinking in detail (elaboration) and think to assess (evaluation) (Munandar, 2009).

Every student has different creative thinking abilities. Low-thinking-skill students demonstrated higher creativity when expecting evaluation in comparison with high-thinkingskills students (Cujbă, 2010). There is a possibility of differences in students' creative thinking abilities by gender (Nurmitasari \& Astuti, 2017). Gender differences are no longer only related to biological problems but develop into differences in abilities between males and females (Ali \& Asrori, 2011). Gender can influence students' mindset in solving and responding to a problem by thinking creatively. There was a difference in creative thinking skills in terms of gender 
(Shubina \& Kulakli, 2019; He \& Wong, 2011; Matud et al., 2007). Various researches state that there was a sign of gender for creative thinking skills that are divided into two groups. One group of researchers agree that males are more creative than females (Stoltzfus et al., 2011; Proudfoot et al., 2015; Singh, 2014). Another group states the opposite result that female students more creative than males (Reuter et al., 2005).

Some research shows that the learning achievements of male students are better than female students, or the achievements of female students are better than male students. Female students' thinking skills better in terms of accuracy, precision than the male student, while the male was a little less conscientious and haste in completing the work (Krutetzky, 1976). The statement shows that the creative thinking abilities of male and female students are different. Another study state that statistically significant differences in the majority of a subject between females and males with women prevalence (Bart et al., 2015). This study indicates that the gender differences between students in year 8 were higher than students in year 11. The results of other studies say that female is weak in matters related to the abstract, so they are considered weak (Ekawati \& Wulandari, 2011). Some state that there are no differences between male and female students (Nurmitasari, 2016).

As stated at the beginning of the introduction, creative thinking skills are included in the $21 \mathrm{st}$ Century skills. Research that examines the 21 st Century skills profile of students will be able to be the basis for policymaking in education as well as the basis of further research. Interestingly, in Indonesia, some previous studies still more focused on the profile of other thinking skills, such as critical (Fauzi \& Sa'diyah, 2019; Rahmawati et al., 2018) or metacognitive thinking skills (Fauzi \& Sa'diyah, 2019; Palennari et al., 2018) rather than creative thinking skills. Creative thinking skills also include essential skills in the 21 st Century. Therefore, in this study, the profile of the creative thinking skills of male and female students is examined. This research will help identify indicators of creative thinking abilities that are weak and need to be improved. In addition, the research of indicators that need to be improved by gender. It is hoped that a solution will be found to improve the ability to think creatively in male and female students in general. This results in an even distribution of creative thinking abilities for males and females in accordance with the need to increase the creative thinking abilities of male and female students.

\section{Method}

The method in this research used descriptive analysis research using quantitative data. Data collection was using tests, interviews, and observation. Research tools related to creativity 
designed in rubrics developed by Bosch (Ismaimuza, 2013). The instrument was assessed and validated by two experts in learning evaluation and three science teachers in Surakarta. Data analysis of tests and interviews using Table 1. Data analysis of observation sheets using descriptive analysis with quantitative data. Variables used in this study include independent variable namely gender and the dependent variable in the form of creative thinking skills Population in this study were grade VII in three junior high schools with different categories of high, medium and low. Class VII in high category schools totaling 32 students, Class VII in medium category schools totaling 31 and class VII in low category schools totaling 31 students. The total of samples is 94 students, consist of 35 male and 59 female students. The sample selection uses a purposive sampling technique.

The ability to think creatively in this study will be divided into three categories, namely high, medium, and low. Data were analyzed using covariance analysis with a significance level of 0.05 ( $\mathrm{P}<0.05)$. Before the covariance analysis, a prerequisite test was carried out, namely normality with the Kolmogorov-Smirnov test and homogeneity test with the Levene's test. Data were analyzed with the help of IBM SPSS Statistics 20. The indicators of thinking ability are divided into three categories, namely, high, medium, and low. The determination of category boundaries is seen in Table 1 .

Table 1. Determination Limits Group.

\begin{tabular}{|c|c|}
\hline Value & Category \\
\hline $\mathbf{s} \geq(\bar{x}+\mathbf{S D})$ & High \\
\hline$(\bar{x}-\mathbf{S D})<\mathrm{s}<(\bar{x}+\mathbf{S D})$ & Medium \\
\hline $\mathbf{s} \leq(\bar{x}-\mathbf{S D})$ & Low \\
\hline
\end{tabular}

Source: (Arikunto, 2010)

$\mathrm{SD}=$ standard deviation

$\bar{x}=$ average student grade

\section{Result and Discussion}

The purpose of this study was to determine the ability of creative thinking junior high school students in science learning by gender. This research was conducted in March 2019. Variables used in this study include free variables, namely gender and the dependent variable, in the form of creative thinking skills. Indicators of creative thinking ability examined in this study are fluency, flexibility, originality, and elaboration (Ismaimuza, 2013). The four indicators of creative thinking ability are by the aspects of creative thinking skills that this development research requires. In addition to these four indicators, in general, can represent the creative 
thinking skills that students must have to face the challenges of the 21 st-century. To find out the ability of students to think creatively by gender, a normality test, and homogeneity test is first performed. Normality and homogeneity test are shown in Table 2

Table 2. Normality and Homogeneity Test

\begin{tabular}{ccccc}
\hline \multirow{2}{*}{ Class } & \multicolumn{2}{c}{$\begin{array}{c}\text { Test of Normality } \\
\text { (Kolmogorov-Smirnov) }\end{array}$} & \multicolumn{2}{c}{$\begin{array}{c}\text { Homogeneity Test } \\
\text { (Levene's test) }\end{array}$} \\
\cline { 2 - 5 } & Sig. & Conclusion & Sig. & Conclusion \\
\hline High & 0.200 & Normal & 0.340 & Homogen \\
Medium & 0.086 & Normal & & \\
Low & 0.200 & Normal & & \\
\hline
\end{tabular}

Based on Table, each class gets sig $>0.05$, so the data is normally distributed. Based on Table 2 , data of creative thinking skills obtained sig $>0.05(0.340>0.05)$, so the data are homogeneous. After the prerequisites for normality and homogeneity test, the results of the one way ANOVA showed in Table 3

Table 3. Summary of the results the one way ANOVA test of creative thinking skills

\begin{tabular}{cccccc}
\hline Source & Type III Sum of Squares & df & Mean Square & F & Sig. \\
\hline Gender & $19892.739^{\mathrm{a}}$ & 1 & 19892.739 & 135.514 & 0.000 \\
\hline
\end{tabular}

Based on Table 3. Show that the sig F count on the ability to think creatively by gender is 135.514 with sig 0.000 ( $\mathrm{sig}<0.05$ ). These results indicate that there are differences in student's creative thinking skills by gender. Based on the analysis, it was concluded that science learning could carry out the different potential in increasing the creative thinking skills of male and female students.

The results of this study indicated there are differences in creative thinking skills between male and female students. Some researchers said that female students are better than male students, or male students are better than female students. The results of this study are in accordance (Syarifah et al., 2016); there are differences in creative thinking skills based on gender. Gender is closely related to biological problems. Increasingly the age, gender is no longer only associated with gender or biological issues, but developed into a difference in the ability to think between female and male (Nafi'an, 2011). Factors affecting the development of thinking ability based on gender include 1) physical (biological) factors in male and female behavior; 2) social factors, individual relationships with one another, such as between family members, fellow friends, etc.; 3) cognitive factors in children's gender development (Santrock, 2014). 
To find out which indicators are high, medium, and low, then analyze using Table 1. Results of tests are grouped into three categories: high, medium, and low. The results of the test and are shown in Table 2.

Table 2. Results of Test to Creative Thinking Skills

\begin{tabular}{|c|c|c|c|c|c|}
\hline \multirow{2}{*}{ Criteria } & \multirow{2}{*}{ Category } & \multicolumn{4}{|c|}{ Number of Students } \\
\hline & & Male & $\%$ & Female & $\%$ \\
\hline Score $\geq 20$ & High & 9 & 25,72 & 14 & 23,73 \\
\hline $10 \leq$ Score $<20$ & Medium & 15 & 42,85 & 28 & 47,46 \\
\hline Score $<10$ & Low & 11 & 31,43 & 17 & 28,81 \\
\hline
\end{tabular}

Based on Table 2., it appears that the average ability of male students is better than females. Based on the data in Table 2, it shows that male students who have a high level of creative thinking skills amount to 9 people, moderate thinking ability level of 15 people and a low level of creative thinking skills of 11 people, with successively the percentage obtained is $25.72 \%$, $42.85 \%$, and $31.43 \%$. Whereas female students have a high level of creative thinking skills, amount to 14 people with a percentage of $23.73 \%$, while a number of 28 students with a percentage of 47.46 and low as many as 17 students with a percentage of $28.81 \%$.

The results of this study are supported (Subarinah, 2013), which states that the ability of male students is better than female students. Male students have a more open mind in this case, and male students have flexible thinking skills. Flexible thinking means not sticking to one thing, but can see from a variety of different perspectives. Male students can think abstractly or unclearly, abstractly, to come up with new ideas that are original in this case means that the aspects of original thinking are better than female students. Girls tend to be careful when answering questions. The way of thinking of these female students is still concrete, so it is difficult to find common patterns in constructing knowledge or answering questions. The data was detailed based on the indicators of the creative thinking skills used in this study. The average percentages in each indicator in creative thinking skills based on the indicators that have been breaking down are shown in Table 3.

Based on Table 3., it can be seen that male students have a high score percentage are flexibility, medium in both originality and fluency, and low for elaboration, while female students have the highest percentage score on fluency, medium for elaboration, and low for originality and flexibility. Male students tend to think smoothly, even if they are given some complex problems. Male students are able to control their minds in focusing on solving the problem based on this indicator of creative thinking skills, unlike female students. 
Table 3. Average Percentage or Mean per Indicator of Creative Thinking Skills

\begin{tabular}{|c|c|c|c|c|}
\hline \multirow{2}{*}{ Indicators of Creative Thinking Skills } & \multicolumn{4}{|c|}{ Gender } \\
\hline & Male & Mean (\%) & Female & Mean (\%) \\
\hline Fluency & 7 & 20 & 25 & 42.38 \\
\hline Flexible & 14 & 40 & 11 & 18.64 \\
\hline Original & 9 & 25.72 & 9 & 15.25 \\
\hline Elaboration & 5 & 14.28 & 14 & 23.73 \\
\hline
\end{tabular}

The highest male creative thinking skills are shown in the indicator of flexibility, while female students are in the indicator of fluency. Male students tend to be flexible in thinking. They have a more flexible way of thinking in response to problems, unlike females who prioritize speed and accuracy. Speed and accuracy indicate that female students think fluently. The creative thinking ability of a male who has a low percentage is fluency and elaboration. This means that students are not fluent in answering and not paying attention to speed and accuracy. They tend to be spontaneous, say what they think about a problem that is a little different. Male students are less able to justify an idea or develop other people's ideas. Thus the ability of creative thinking of male students' elaboration indicators is low. Female students have a low percentage of originality and flexibility. Female students who tend to have speed and accuracy in answering will tend to be weak to come up with unique ideas and tend to give answers that are correct compared to having to think of other different and new answers.

There is a great impact of gender (Piaw, 2013) on the components of creative thinking skills. The results of this study are also supported by the characteristics of male and female students (Handayani \& Sugiarti, 2002) through emotional and intellectual differences. Male students are very aggressive, not emotional, more objective, logical, and like exact knowledge, in contrast to female students who are not too aggressive and not too independent, more emotional, more subjective, less like exact, and less logical.

In problem-solving male students have better abilities than females (Lin et al., 2012). The matter of the ability to think creatively is divergent, which requires understanding in completing it, so it is said that male students have a slightly better ability than females. Creativity (Shubina, 2017) has to be reinforced among students as interrelated cognitive processes that may enhance different types of thinking, ways of study, productivity, experience, the applicability of gained knowledge. The observation was carried out during the learning process. Results of observation sheets shown in Table 4. 
Table 4. Results of Test to Creative Thinking Skills

\begin{tabular}{ccccc}
\hline Indicators of Creative Thinking & \multicolumn{4}{c}{ Gender } \\
\cline { 2 - 5 } Skills & Male (\%) & Category & Female (\%) & Category \\
\hline Fluency & 26.48 & Medium & 42.37 & High \\
Flexible & 43.11 & High & 24.55 & Medium \\
Original & 18.04 & Low & 12.46 & Low \\
Elaboration & 12.37 & Low & 20.62 & Low \\
\hline
\end{tabular}

In general, the results of observations included: (1) male and female students do not immediately answer when the teacher gives a question; (2) female students tend to answer questions as listed in the book; (3) female students answer questions such as the example given by the teacher; (4) male students tend to answer with answers outside the book or sample but the answers given are not original; (5) female and male students, both of whom have not been able to give ideas about a problem with several different points of view; and (6) female and male students, both of whom are less able to create their ideas that are new and different than usual.

Fluency refers to the truth and diversity of answers given by students, the aspect of flexibility refers to the different ways given by students in solving problems. In contrast, novelty refers to the answers given unusual to the level of student knowledge in general. It refers to new ways that are displayed students and new ways that are a combination of knowledge obtained by previous students (Krisnawati, 2012). Based on research (Ulfa et al., 2018), it showed the highest indicator of creative thinking skills obtained by flexibility, then fluency, elaboration, and lowest in originality. The aspect of fluency that has the highest value can be made possible in learning that habits are inserted in the fluency aspect. This custom aspect of fluency can be in the form of allowing students to ask, answer questions, give opinions, suggestions, and criticize. This opportunity will encourage students to highlight aspects of fluency, such as generating many ideas or answers in a problem (Afidah, 2012).

Indicators of flexibility in the ability of creative thinking can mean that students can produce variations of ideas to solve problems or give answers; students can see a problem or question with multiple viewpoints. The flexibility aspect is included in the medium category, and it can be caused by the less optimal implementation of scientific learning (Ulfa et al., 2018). Less optimal implementation of cognitive learning can cause students to think less flexible; in other words, the ability to think flexibly is not produced optimally. Students are only fixated on the teacher giving examples or the knowledge they have gained from learning resources. The ability to see from a variety of perspectives is limited. 
The essential characteristic in novelty is different from the others or previously existed. Flexibility is seen by showing the productivity of ideas used to solve a problem; the smoothness sees fluency of students in producing ideas, answers, solutions, and different ideas according to questions, conditions, and requests. In this study, it was concluded that the aspect of originality is relatively low. This is not in line with (Ulfa et al., 2018); the low aspect of originality can be caused by the low aspects of observing, asking, exploring, and associating in learning the 2013 curriculum with a scientific approach.

The elaboration aspect is included in the medium category. In Tables 3 and 4, aspects of elaboration in female students are better than male students. This statement is supported by (Bart et al., 2015) that the elaboration of female students was higher than male students. Elaboration on aspects of creative thinking ability can mean that students can find the truth in a question or a problem and have a reason that can be justified in reaching a decision. Elaboration aspects obtained in the exploration phase. Explorations require students to find and explore information. Searching and extracting information can be done by reading or experimenting. Work done by students on the elaboration aspect tends to be systematic (Ulfa et al., 2018).

A subject in these interviews were students and teacher. In this research, interviews as supporting data. Interviews are useful for confirming answers, reasons, and explanations of students about creative thinking skills. In general, interviews concluded that male and female students have difficulty getting the original answer or ideas to solve the problem. Female students tended to be fluently in giving answers, but the answers they were given shown in a textbook or teacher explanation so less in original. In contrast, male students tended to be flexible in providing answer options, but less in fluency.

The interviews support previous data that there are differences in the creative thinking abilities of male and female students (Subarinah, 2013). The weak original thinking ability in this study is also supported by (Bart et al., 2015) that male and female students tend to have the same ability in terms of original thinking. Based on the results of interviews, gender differences will affect the way to solve a question or problem in male and female students (Irvani et al., 2016) states that male students tend to have difficulty understanding questions. This was answered when the interview data was obtained. Male students need time to understand questions by reading back and being more careful, in contrast to women who are easier to understand questions so that they can provide answers more quickly and smoothly. It is also the 
ability to understand questions that make female students can elaborate on aspects better than male students.

\section{Conclusion}

The result of this study showed that there are differences in student's creative thinking skills by gender. The male students have a high percentage in fluency, the medium percentage in originality, and a low percentage in both flexible and elaboration. Female students have a high percentage of inflexible, a medium percentage in elaboration, and a low percentage in both originality and fluency. The expectation of researchers with the existence of this research is that the government, specifically the education agency and education practitioners, namely teachers will be able to overcome or provide learning strategies that are used in general, both male and female. This research is expected to be able to be taken into consideration for other researchers to investigate further and find ways to overcome the differences in creative thinking skills between male and female students.

\section{References}

Abraham, A. (2016). Gender and creativity: An overview of psychological and neuroscientific literature. Brain Imaging and Behavior, 10(2), 609-618.

Afidah, I. N. (2012). Pengaruh penerapan metode Socratic Circles disertai media gambar terhadap kemampuan berfikir kreatif siswa. Jurnal Pendidikan Biologi, 4(3), 1-15.

Ali, M., \& Asrori, M. (2011). Psikologi Remaja Perkembangan Peserta Didik. Jakarta: PT Bumi Aksara.

Arikunto, S. (2010). Prosedur Penelitian Suatu Pendekatan dan Praktik. Jakarta: PT Rineka Cipta.

Azhari, A., \& Somakim, S. (2014). Peningkatan Kemampuan Berpikir Kreatif Matematik Siswa Melalui Pendekatan Konstruktivisme Di Kelas VII Sekolah Menengah Pertama (SMP) Negeri 2 Banyuasin III. Jurnal Pendidikan Matematika, 8(1), 1-12.

Bahriah, E. S. (2012). Pengembangan multimedia interaktif kesetimbangan kimia untuk meningkatkan literasi sains siswa (Doctoral dissertation, Universitas Pendidikan Indonesia). Retrieved from http://repository.upi.edu/9901/

Bart, W. M., Hokanson, B., Sahin, I., \& Abdelsamea, M. A. (2015). An investigation of the gender differences in creative thinking abilities among $8^{\text {th }}$ and $11^{\text {th }}$-grade students. Thinking Skills and Creativity, 17, 17-24.

Carin, A. A., \& Sund, R. B. (2017). Model Silabus Mata Pelajaran SMP/ MTs. Columbus: Merrill Publishing Company.

Cujbă, T. O. (2010). Considerations on Creativity Motivation. Buletinul Universitanii Petrol Gaze Din Ploiesti. Ştiinele Educanie, LXII(2), 154-159.

Ekawati, A., \& Wulandari, S. (2011). Perbedaan jenis kelamin terhadap kemampuan siswa dalam mata pelajaran matematika (studi kasus sekolah dasar). Jurnal Socioscienta, 3(1), 1924. 
Fauzi, A. \& Sa'diyah, W. (2019). Students' metacognitive skills from the viewpoint of answering biological questions: Is it already good? Jurnal Pendidikan IPA Indonesia, 8(3), 317-327.

Ghufron, M. N., \& Risnawati, S. R. (2014). Teori-teori Psikologi. Yogyakarta: Ar-Ruzz media.

Gie, T. (2003). Teknik-teknik Berpikir Kreatif. Yogyakarta: Multi Pressindo.

Handayani, T., \& Sugiarti. (2002). Konsep dan Teknik Penelitian Gender. Malang: Universitas Muhamadiyah Malang Press.

He, W. J., \& Wong, W. C. (2011). Gender differences in creative thinking revisited: Findings from analysis of variability. Personality and Individual Differences, 51(7), 807-811.

Irvani, F. A., Suharto, S., \& Kurniati, D. (2016). Profil berpikir kreatif siswa laki-laki dan perempuan kelas VIII SMP Nuris Jember dalam menyelesaikan soal cerita pokok bahasan segiempat. Kadikma, 7(1), 105-113.

Ismaimuza, D. (2013). Kemampuan berpikir kritis dan kreatif matematis siswa SMP melalui pembelajaran berbasis masalah dengan strategi konflik kognitif. Sains Humanika, 63(2), 3337.

Krisnawati. (2012). Kreativitas siswa dalam memecahkan masalah matematika divergen berdasarkan kemampuan matematika siswa. MATHEdunesa, 1(1), 1-8.

Krutetzky. (1976). The Schoolchildren Teaching and Education Psychology.

Kurnia, F., \& Fathurohman, A. (2014). Analisis bahan ajar fisika SMA kelas XI di Kecamatan Indralaya Utara berdasarkan kategori literasi sains. Jurnal Inovasi dan Pembelajaran Fisika, 1(1), 43-47.

Lin, W. L., Hsu, K. Y., Chen, H. C., \& Wang, J. W. (2012). The relations of gender and personality traits on different creativities: A dual-process theory account. Psychology of Aesthetics, Creativity, and the Arts, 6(2), 112-123.

Mahmudi, A. (2009). Mengembangkan kemampuan berpikir kreatif siswa melalui pembelajaran topik pecahan. In Seminar Nasional Aljabar, Pengajaran, dan Terapannya. Yogyakarta (Vol. 31).

Matud, M. P., Rodríguez, C., \& Grande, J. (2007). Gender differences in creative thinking. Personality and individual differences, 43(5), 1137-1147. doi: 10.1016/j.paid.2007.03.006

Munandar, U. (2009). Mengembangkan bakat dan kreativitas anak sekolah. Penuntun bagi guru dan Orang Tua. Jakarta: Grasindo.

Nafi'an, M. (2011). Kemampuan Siswa Dalam Menyelesaikan Soal Cerita ditinjau dari Gender Sekolah Dasar. Matematika Dan Pendidikan Karakter Dalam Pembelajaran. Yogyakarta: UNY.

Nurmitasari. (2016). Pembelajaran team assissted individualization pada lingkaran ditinjau dari jenis kelamin dan kemampuan awal. Journal Eksponen STKIP Muhammadiyah Kotabumi, 6(2), 67-77.

Nurmitasari, N., \& Astuti, R. (2017). Tingkat berpikir kreatif siswa MTs. pada bangun datar ditinjau dari jenis kelamin. Jurnal e-DuMath, 3(2), 118-128.

Palennari, M., Taiyeb, M., \& Saenab, S. (2018). Profile of students' metacognitive skills based on their learning style. In Journal of Physics: Conference Serie, 1028.

Piaw, C. Y. (2013). Effects of gender and thinking style on students' creative thinking ability. Procedia-Social and Behavioral Sciences, 116(2014), 5135-5139.

Prayekti. (2006). Penerapan Pendekatan sains teknologi masyarakat pada pembelajaran IPA di SD. Jurdik \& Hum, 9, 1-7. 
Proudfoot, D., Kay, A. C., \& Koval, C. Z. (2015). Gender bias in the attribution of creativity: Archival and experimental evidence for the perceived association between masculinity and creative thinking. Psychological Science, 26(11), 1751-1761.

Rahmawati, S. Y. D., Ashadi, \& Susilowati, E. (2018, September). Student's profile about critical thinking ability on hydrocarbon compounds concept. In AIP Conference Proceedings (Vol. 2014, No. 1, p. 020047). AIP Publishing.

Rashid, T., \& Asghar, H. M. (2016). Technology use, self-directed learning, student engagement, and academic performance: Examining the interrelations. Computers in Human Behavior, 63, 604-612.

Reuter, M., Panksepp, J., Schnabel, N., Kellerhoff, N., Kempel, P., \& Hennig, J. (2005). Personality and biological markers of creativity. European Journal of Personality: Published for the European Association of Personality Psychology, 19(2), 83-95.

Santrock, J. (2014). Psikologi Pendidikan Edisi 5 Jilid 1. Jakarta: Salemba Humanika.

Shubina, I. (2017). Creativity in psychotherapy: the possibilities of its utilization. The European Proceeding of Social \& Behavioural Sciences, 22, 99-111.

Shubina, I., \& Kulakli, A. (2019). Critical Thinking, Creativity, and Gender Differences for Knowledge Generation in Education. Literacy Information and Computer Education Journal (LICEJ), 10(1), 3086-3093.

Silver, E. A. (1997). Fostering creativity through instruction rich in mathematical problem solving and problem posing. $Z d m, 29(3), 75-80$.

Singh, S. K. (2014). Creative thinking among school students: comparisons across achievement category, gender, and residential background. Research Journal of Social Science \& Management, 4(1), 62-67.

Stoltzfus, G., Nibbelink, B. L., Vredenburg, D., \& Hyrum, E. (2011). Gender, gender role, and creativity. Social Behavior and Personality: An International Journal, 39(3), 425-432.

Subarinah, S. (2013, November). Profil berpikir kreatif siswa dalam memecahkan masalah tipe investigasi matematik ditinjau dari perbedaan gender. In Seminar Nasional Matematika dan Pendidikan Matematika, 541-548. Yogyakarta, Universitas Negeri Yogyakarta.

Syarifah, H., Indriwati, S. E., \& Corebima, A. D. (2016). Pengaruh Strategi Pembelajaran Reading Questioning and Answering (RQA) dipadu Think Pair Share (TPS) terhadap keterampilan metakognitif siswa laki-lai dna siswa perempuan SMAN di Kota Malang. Jurnal pendidikan;Teori, Penelitian, dan Pengembangan, 1(5), 801-805.

Torrance, E. P. (1965). Scientific views of creativity and factors affecting its growth. Creativity and Learning, 94(3), 663-681.

Ulfa, A., Ruzyati, M., Pujiastuti, P., San, S. M., \& Prayitno, B. A. (2018). Profil kemampuan berpikir kreatif siswa laki-laki dan perempuan di sebuah SMA Negeri Surakarta. In Proceeding Biology Education Conference: Biology, Science, Enviromental, and Learning (Vol. 15, No. 1, pp. 532-540). 